\title{
Efektivitas Pelaksanaan Terapi Empati terhadap Kemampuan Manejemen Konflik Perawat Pelaksana di RSUD H. Hanafie Muara Bungo Tahun 2019
}

\author{
Dewi Marlina $^{*}$, Yulastri Arif ${ }^{2}$, Mira Susanti ${ }^{3}$ \\ ${ }^{1,2}$ Fakultas Keperawatan, Universitas Andalas, \\ Limau Manis, Kec. Pauh, Kota Padang, Sumatera Barat, Indonesia, 25163 \\ ${ }^{3}$ RSUP Dr. M. Djamil Padang, Sumatera Barat, Indonesia, 25163 \\ *Correspondence email: dewimarlina380@gmail.com
}

\begin{abstract}
Abstrak. Konflik adalah sebuah proses interaksi yang dihasilkan karena adanya ketidakcocokan, ketidaksetujuan dan ketidaksesuaian antara dua pihak atau lebih. terdapat 52 kasus konflik di RSUD H. Hanafie yang terjadi antara perawat di ruang rawat inap dengan bermacam macam pemicu, seperti perbedaan pendapatan, kesalahpahaman, merasa kurang dihargai, merasa kurangnya toleransi dan ketidakdisiplinan. Penelitian bertujuan untuk menganalisis efektivitas pelaksanaan terapi empati terhadap kemampuan manajemen konflik perawat pelaksana di RSUD H. Hanafie Muara Bungo. Jenis penelitian adalah kuantitatif menggunakan desain penelitian "Quasy Experimental Pre-Post Test With Control Group. Populasi dalam penelitian ini adalah seluruh perawat pelaksana yang ada di ruang rawat inap RSUD Hanafie Muara Bungo dengan jumlah 129 orang. Sampel perawat pelaksana berjumlah 34 responden. Pengambilan sampel dengan simple random sampling. Hasil penelitian ada pengaruh yang signifikan dari pelaksanaan terapi empati terhadap pengetahuan $(\mathrm{p}=0,002)$, sikap $(\mathrm{p}=0,004)$ dan keterampilan $(\mathrm{p}=0,008)$. Diharapkan perawat untuk sama-sama menghindari konflik, mau memperhatikan pendapat dan kepentingan orang lain dan menyelesaikan konflik dengan tanpa merugikan pihak lain.
\end{abstract}

Kata Kunci : Terapi Empati, Manajemen Konflik, Perawat Pelaksana

\begin{abstract}
Conflict is an interaction process that results from a mismatch, disagreement and mismatch between two or more parties. There were 52 cases of conflict in the H. Hanafie Hospital that occurred between nurses in the inpatient room with various triggers, such as differences in income, misunderstandings, feeling less valued, feeling lack of tolerance and indiscipline. This study aims to analyze the effectiveness of the implementation of empathy therapy on the conflict management abilities of nurses in RSUD H. Hanafie Muara Bungo. This type of research is quantitative using the research design "Quasy Experimental Pre-Post Test With Control Group. The population in this study were all nurses in the inpatient room of the Hanafie Muara Bungo Regional Hospital with a total of 129 people. The sample of implementing nurses was 34 respondents. Sampling with simple random sampling. The results of the study there was a significant effect of the implementation of empathy therapy on knowledge $(p=0.002)$, attitude $(p=0.004)$ and skills $(p=0.008)$. It is hoped that the nurses will both avoid conflict, be willing to pay attention to the opinions and interests of others and resolve conflicts without harming other parties.
\end{abstract}

Keywords: Empathy Therapy, Conflict Management, Nursing Implementation

\section{PENDAHULUAN}

Rumah sakit merupakan fasilitas pelayanan publik dalam bidang kesehatan yang memegang prinsip dalam memberikan pelayanan (Mayfield, 2018). Menurut Atmaja (2018), rumah sakit memiliki prinsip peningkatan mutu pelayanan dengan memenuhi kebutuhan pasien, mengukur dan menilai pelayanan yang diberikan. Jadi prinsip pelayanan publik di rumah sakit akan dapat memperbaiki proses pelayanan dan meningkatkan mutu sumber daya manusia yang bekerja di rumah sakit.

Sumber daya manusia yang sangat berperan dalam pelayanan kesehatan di rumah sakit adalah perawat (Fitri \& Kamil, 2018). Perawat merupakan tenaga kesehatan yang diberikan kewenangan untuk memberikan asuhan kepada pasien (Brunero, 2017). Jumlah perawat yang lebih banyak dari SDM lainnya akan menyebabkan kecendrungan terjadinya konflik dengan SDM yang ada di rumah sakit (Basogul, 2016). Jadi perawat berpotensi mengalami konflik antara perawat dengan perawat, perawat dengan pasien maupun masalah yang terjadi antar perawat dengan profesi lainnya.

Konflik adalah sebuah proses interaksi yang dihasilkan karena adanya ketidakcocokan, ketidaksetujuan dan ketidaksesuaian antara dua pihak atau lebih (Fernando, 2017). Setiap individu di dalam organisasi merupakan penyebab timbulnya konflik, baik dilakukan secara sadar maupun tidak (Bassere et al, 2017). Pada perawat potensi terjadinya konflik cukup besar karena perawat merupakan SDM dengan jumlah banyak dan memberikan pelayanan selama 24 jam kepada klien.

Konflik yang terjadi antar perawat Australia dilaporkan sebanyak 38\%, Amerika 32\% dan di Korea sebanyak 23\% (Hidaya, 2017). Di Indonesia menurut Noviasari (2018), setiap rumah sakit memiliki laporan konflik yang terjadi antar perawat, rata-rata sekitar $15 \%$ perawat yang ada di rumah sakit mengalami konflik setiap tahunnya. 
Konflik tentunya memberi dampak terhadap pelayanan sehingga dibutuhkan strategi untuk mengatasinya. Menurut Fitri \& Kamil (2018) di RSUD dr. Zainoel Abidin Banda Aceh menemukan hasil bahwa hampir setiap minggu terjadi konflik antar perawat yang bertugas di rumah sakit. Beberapa sumber konflik adalah perbedaan cara pandang antara manajemen dan staf, jumlah sumber daya yang terbatas sehingga mereka memiliki tingkat stress yang lebih tinggi, perbedaan tujuan kerja dan kompetisi antar kelompok (Mayfield, 2018). Berdaskan hal tersebut maka diperlukan upaya yang dapat menyelesaikan penyebab konflik. Konflik tidak akan pernah bisa dihindari, namun penting dilakukan manajemen konflik yang tepat agar tidak berdampak kepada pelyanan.

Kurangnya rasa empati dari diri individu merupakan prediktor utama penyebab konflik (Kahriman et al, 2016). Tingginya rasa empati dalam diri perawat dapat menumbuhkan rasa kepedulian dan rasa iba yang kemudian memunculkan perilaku menolong dan menghindari konflik (Halpern, 2017). Perilaku menolong mempunyai tujuan untuk mendukung kepentingan dan kesejahteraan orang lain (Jani, 2017). Oleh karena itu sangat penting bagi perawat memiliki empati.

Terapi empati (Empaty Care Training) adalah suatu bentuk kegiatan pelatihan empati yang dirancang untuk meningkatkan empati (Gayanti, 2018). ECT ini dirancang berdasarkan aspek-aspek empati yaitu perspective taking, fantasy, empathic concern dan personal distress (Fatimatuzzahro, 2017). Jadi dapat disimpulkan bahwa ECT merupakan pelatihan yang bertujuan untuk meningkatkan empati yang akan berpengaruh terhadap perilaku salah satunya adalah tolong menolong dan mampu merasakan permasalahan dari sudut pandang orang lain.

Pada komponen ini pelatihan fokus pada individu agar mampu merasakan adanya perasaan yang sama antara dirinya dan orang lain yang ada dalam kehidupannya (Gayanti, 2018). Hal ini apabila dilakukan dengan baik tentunya akan sangat efektif untuk memunculkan empati. Menurut Marettih (2016) dan (Gayanti, 2018), terapi empati (Empaty Care Training/ECT) terdiri dari 5 sesi atau tahapan, yaitu knowing, think and fell, $i$ and my own, $i$ care to other dan personal distress.

Efektivitas pelaksanaan terapi empati untuk meningkatkan empati dan menciptakan manajemen konflik yang baik didukung oleh berbagai penelitian. Penelitian Sarmiento et al (2017) membuktikan bahwa empathy training sangat efektif untuk meningkatkan empati, perkembangan pelatihan eksperimental telah menunjukkan hasil yang positif. Berkhout \& John (2015) juga mendapati hasil bahwa terapi training berdampak positif bagi peserta. Jadi dengan adanya terapi empati, peserta akan diberikan kesempatan untuk berpartisipasi dan diberikan materi mengenai pemahaman emosi agar dapat merasakan apa yang dirasakan oleh orang sehingga manajemen dalam menghadapi konflik semakin baik.

Penelitian Klimecki (2019) membuktikan bahwa pelatihan empati dan empati yang dimiliki seseorang dapat mempengaruhi konflik yang terjadi baik secara individu maupun konflik antar kelompok. Selanjutnya Seehausen et al (2012) juga menemukan hasil bahwa dengan rasa empati yang tinggi dapat membuat seseorang mengatur emosinya dan menyelesaikan konflik dengan baik. lebih lanjut juga dismpulkan bahwa empati dapat merangsang pemrosesan emosi yang lebih intens membantu mengubah dan meningkatkan kemampuan manajemen konflikk (pengetahuan, sikap dan keterampilannya dalam menyelesaikan konflik).

\section{METODE}

Penelitian ini merupakan penelitian kuantitatif dengan menggunakan desain "Quasy Experimental PrePost Test With Control Group".

Populasi dalam penelitian ini adalah seluruh perawat pelaksana yang ada di ruang rawat inap RSUD Hanafie Muara Bungo dengan jumlah 129 orang. Berdasarkan rumus perhitungan sampel Lamshow, sampel dalam penelitian berjumlah 34 (17 kelompok intervensi dan 17 kelompok kontrol). Setelah mendapatkan jumlah sampel atau besarnya sampel setiap rumah sakit, selanjutnya pengambilan sampel di tiap rumah sakit menggunakan tekhnik simple random sampling. Uji statistik yang digunakan untuk melihat perbedaan efektivitas antara kelompok intervensi dengan kelompok kontrol adalah jika data berdistribusi normal menggunakan uji $\mathrm{t}$ independen dan mann whitney jika data tidak berdistri busi normal. Variabel dikatakan ada pengaruh/efektif/ada perbedaan jika $\mathrm{p}$ value $\leq 0,05(\mathrm{p}<$ $\alpha)$.

Penelitian ini telah memiliki surat lolos uji etik dari Komite Etik Penelitian Fakultas Kedokteran Universitas Andalas dengan No: 167/KEP/FK/2020. Tahapan dalam penelitian ini adalah peneliti melakukan koordinasi dengan pihak manajerial RSUD Hanafie Muara Bungo terkait jadwal, tempat dan peserta pelatihan. Peneliti mengumpulkan responden sesuai dengan kriteria inklusi yang telah ditentukan. Peneliti memperkenalkan diri, menjelaskan maksud dan tujuan serta meminta kesediaan responden dengan cara menanda tangani lembar persetujuan (jumlah responden di setiap ruangan sesuai dengan jumlah yang didapati saat perhitungan sampel ruangan).

Setelah responden mendapatkan penjelasan maksud dan tujuan penelitian serta menanda tangani informed consent, maka:

1. Di hari pertama

a. Persiapan

Mempersiapkan alat dan bahan yang dibutuhkan dalam proses terapi. Mempersiapkan kehadiran 
dan kelengkapan peserta terapi empati. Alat dan Bahan yaitu daftar hadir,alat tulis, name tag.

b. Pembukaan (10 Menit)

Kegiatan dimulai dengan pembukaan dari Kepala Bidang Keperawatan dan penjelasan tujuan serta manfaat pelatihan sebagai usaha membangun komitmen selama pelatihan berlangsung.

c. Pre Test (30 Menit)

Peneliti melakukan pengukuran pengetahuan dan sikap tentang empati serta gaya penyelesaian konflik pada responden dengan memberikan kuesioner pre test yang telah disiapkan. Peneliti membacakan isi kuesioner, peserta pelatihan memberikan jawaban pada kolom jawaban yang tersedia.

d. Penyampaian materi empati dan konflik oleh terapis Ibu DR. Yulastri Arif, M.Kep (60 menit) dan Ibu Fina Afrianti, S.Ps, M.Psi (60 menit).

e. Sesi tanya jawab ( 30 Menit)

f. Pelaksanaa terapi empati, meliputi :
a) Mari mencerahkan jiwa raga (15 menit)
b) Pohon Kebaikan (20 Menit)
c) Mari Melihat Film Kebaikan (40 menit)
d) Snack untukmu (20 menit)
e) Mari memahami orang lain : (50 menit)
f) Memaknai nilai empati : (25 menit)

2. Di hari kedua

a. Persiapan

Mempersiapkan alat dan bahan yang dibutuhkan dalam proses terapi. Mempersiapkan kehadiran dan kelengkapan peserta terapi empati. Alat dan Bahan yaitu daftar hadir,alat tulis, name tag sesuai jumlah peserta.

b. Memaknai nilai empati (30 Menit)

c. Mari mengenali diri : (30 Menit)

d. Yang Ku Butuhkan : (20 Menit)

e. Tanggapan baikku untukmu : (40 Menit)

f. Penutupan : (30 Menit)

Setelah pelaksanaan terapi empati selesai dilaksanakan, di hari berikutnya peserta melakukan tugas dan fungsinya sebagai perawat pelaksana sebagaimana biasanya dan didampingi peneliti selama 2 minggu. Kemudian peneliti mengumpulkan responden untuk melakukan pengukuran pengetahuan dan sikap serta gaya penyelesaian konflik perawat dengan memberikan kuesioner post test yang telah disiapkan. Peneliti membacakan isi kuesioner, peserta pelatihan memberikan jawaban pada kolom jawaban yang tersedia.

\section{HASIL DAN PEMBAHASAN}

Tabel 1. Rata-rata Kemampuan Manajemen Konflik (Pengetahuan, Sikap, Keterampilan) Perawat Pelaksana Sesudah Pelaksanaan Terapi Empati $(n=34)$

\begin{tabular}{|c|c|c|c|c|c|}
\hline No & Kemampuan Manajemen Konflik & Mean & Min & Max & SD \\
\hline \multirow[t]{3}{*}{1} & Pengetahuan & & & & \\
\hline & Post Test Intervensi & 4.53 & 4 & 5 & 0.514 \\
\hline & Post Test Kontrol & 3.06 & 2 & 4 & 0.556 \\
\hline \multirow[t]{3}{*}{2} & Sikap & & & & \\
\hline & Post Test Intervensi & 50.12 & 44 & 58 & 3.706 \\
\hline & Post Test Kontrol & 40.12 & 34 & 49 & 3.257 \\
\hline \multirow[t]{3}{*}{3} & Keterampilan & & & & \\
\hline & Post Test Intervensi & 90.71 & 84 & 97 & 3.584 \\
\hline & Post Test Kontrol & 70.71 & 65 & 77 & 2.687 \\
\hline \multirow[t]{3}{*}{4} & $\begin{array}{l}\text { Kumulatif } \\
\text { Kemampuan Manajemen Konflik }\end{array}$ & & & & \\
\hline & Post Test Intervensi & 145.35 & 135 & 155 & 5.700 \\
\hline & Post Test Kontrol & 113.88 & 109 & 119 & 2.956 \\
\hline
\end{tabular}

Berdasarkan tabel 1 menunjukkan rerata pengetahuan, sikap dan keterampilan kemampuan manajemen konflik kelompok intervensi lebih besar dibandingkan kelompok kontrol. Berdasarkan hal tersebut maka dapat disimpulkan bahwa kemampuan manajemen konflik pada kelompok intervensi lebih tinggi peningkatannya dibandingkan dengan kelompok kontrol.

Tabel 2. Pengaruh Perlakuan terhadap Kemampuan Manajemen Konflik (Pengetahuan, Sikap, Keterampilan) Perawat Pelaksana pada Kelompok Intervensi dan Kontrol $(n=34)$

\begin{tabular}{|c|c|c|c|c|c|c|c|}
\hline \multirow{2}{*}{ No } & \multirow{2}{*}{ Kemampuan Manajemen Konflik } & \multicolumn{3}{|c|}{ Kelompok Intervensi } & \multicolumn{3}{|c|}{ Kelompok Kontrol } \\
\hline & & Mean & $\mathbf{N}$ & p Value & Mean & $\mathbf{n}$ & p Value \\
\hline \multirow[t]{3}{*}{1} & Pengetahuan & & & & & & \\
\hline & Pre Test & 3.00 & 17 & 0.002 & 2.94 & 17 & 0.163 \\
\hline & Post Test & 4.53 & & & 3.06 & & \\
\hline \multirow[t]{3}{*}{2} & Sikap & & & & & & \\
\hline & Pre Test & 40.06 & 17 & 0.004 & 39.94 & 17 & 0.726 \\
\hline & Post Test & 50.12 & & & 40.12 & & \\
\hline
\end{tabular}


Dewi Marlina et al, Efektivitas Pelaksanaan Terapi Empati terhadap Kemampuan Manejemen Konflik Perawat Pelaksana di RSUD H. Hanafie Muara Bungo Tahun 2019

\section{$3 \quad$ Keterampilan}

Pre Test

Post Test

\begin{tabular}{llllll}
70.76 & 17 & 0.008 & 70.65 & 17 & 0.579 \\
90.71 & & & 70.71 & & \\
& & & & & \\
113.82 & 17 & 0.007 & 113.53 & 17 & 0.502 \\
145.35 & & & 113.88 & & \\
\hline
\end{tabular}

Berdasarkan tabel 2 tentang pengaruh perlakuan terhadap kemampuan manajemen konflik (pengetahuan, sikap, keterampilan) perawat pelaksana pada kelompok intervensi dengan menggunakan uji statistik paired samplet-test (t-dependen) didapati $\mathrm{p}$ value pengetahuan 0,002, sikap 0,004 dan keterampilan 0,008 dan secara kumulatif didapatkan 0,007. Sedangkan pada kelompok kontrol didapati $\mathrm{p}$ value pengetahuan 0,163 , sikap 0,726 dan keterampilan 0,579 dan secara kumulatif didapatkan 0,502 . Hal ini berarti ada pengaruh yang signifikan dari pelaksanaan terapi empati terhadap kemampuan manajemen konflik perawat pelaksana di RSUD $\mathrm{H}$. Hanafie Muara Bungo dan tidak ada pengaruh pada perawat pelaksana di RSUD Sultan Thaha Syaifudin Tebo.

Tabel 3. Perbedaan Kemampuan Manajemen Konflik (Pengetahuan, Sikap, Keterampilan) Perawat Pelaksana Sebelum dan Sesudah Diberikan Perlakuan antara Kelompok Intervensi dengan Kelompok Kontrol $(n=34)$

\begin{tabular}{|c|c|c|c|c|c|c|c|c|}
\hline \multirow{2}{*}{ No } & \multirow{2}{*}{$\begin{array}{c}\text { Kemampuan } \\
\text { Manajemen Konflik }\end{array}$} & \multicolumn{2}{|c|}{ Pre Test } & \multirow[t]{2}{*}{ p Value } & \multicolumn{2}{|c|}{ Post Test } & \multirow[t]{2}{*}{ p Value } & \multirow{2}{*}{ Selisih } \\
\hline & & Mean & SD & & Mean & SD & & \\
\hline \multirow[t]{3}{*}{1} & Pengetahuan & & & & & & & \\
\hline & Kelompok Intervensi & 3.00 & 0.612 & 0.789 & 4.53 & 0.514 & 0.003 & 1.529 \\
\hline & Kelompok Kontrol & 2.94 & 0.659 & & 3.06 & 0.556 & & 0.118 \\
\hline \multirow[t]{3}{*}{2} & Sikap & & & & & & & \\
\hline & Kelompok Intervensi & 40.06 & 2.164 & 0.902 & 50.12 & 3.706 & 0.01 & 10.05 \\
\hline & Kelompok Kontrol & 39.94 & 3.269 & & 40.12 & 3.257 & & 0.176 \\
\hline \multirow[t]{3}{*}{3} & Keterampilan & & & & & & & \\
\hline & Kelompok Intervensi & 70.76 & 2.862 & 0.903 & 90.71 & 3.584 & 0.005 & 19.94 \\
\hline & Kelompok Kontrol & 70.65 & 2.737 & & 70.71 & 2.687 & & 0.059 \\
\hline \multirow[t]{3}{*}{4} & Kemampuan Manajemen Konflik & & & & & & & \\
\hline & Kelompok Intervensi & 113.82 & 4.050 & 0.799 & 145.35 & 5.700 & 0.002 & 31.52 \\
\hline & Kelompok Kontrol & 113.53 & 2.427 & & 113.88 & 2.956 & & 0.353 \\
\hline
\end{tabular}

Menunjukkan tentang perbedaan rata-rata kemampuan manajemen konflik (pengetahuan, sikap, keterampilan) perawat pelaksana sebelum dan sesudah diberikan perlakuan antara kelompok intervensi dengan kelompok kontrol dengan uji statistik t-independen didapati $\mathrm{p}$ value pre test pengetahuan $0,789(\mathrm{p}>0,05)$, sikap 0,902 ( $p>0,05)$, keterampilan $0,903(p>0,05)$ dan kemampuan manjemen konflik secara kumulatif $0,799(\mathrm{p}>0,05)$ yang artinya tidak ada perbedaan ratarata pre test kemampuan manajemen konflik di RSUD H. Hanafie Muara Bungo dengan RSUD Sultan Thaha Syaifudin Tebo dan hal ini juga dapat diartikan bahwa data tersebut homogen.

Selanjutnya perbedaan rata-rata kemampuan manajemen konflik (pengetahuan, sikap, keterampilan) antara kelompok intervensi dengan kelompok kontrol dengan uji statistik t-independen didapati skor rata-rata post test pengetahuan kelompok intervensi 4,53, kelompok kontrol 3,06 dengan $\mathrm{p}$ value $0,003(\mathrm{p}<0,05)$ yang artinya ada perbedaan pengetahuan perawat pelaksana di RSUD H. Hanafie Muara Bungo dengan RSUD Sultan Thaha Syaifudin Tebo. Hal ini berarti perlakuan yang diberikan peneliti pada kelompok intervensi telah berhasil meningkatkan pengetahuannya.
Kemudian skor rata-rata post test sikap kelompok intervensi 50.12 dan rata-rata post test sikap kelompok kontrol 40.12 dengan $\mathrm{p}$ value $0,010(\mathrm{p}<0,05)$ yang artinya yang artinya ada perbedaan sikap perawat pelaksana di RSUD H. Hanafie Muara Bungo dengan RSUD Sultan Thaha Syaifudin Tebo. Hal ini berarti perlakuan yang diberikan peneliti pada kelompok intervensi telah berhasil meningkatkan sikapnya.

Kemudian skor rata-rata post test keterampilan kelompok intervensi $90 ., 71$ dan rata-rata post test keterampilan kelompok kontrol 70,71 dengan $\mathrm{p}$ value $0,005(\mathrm{p}<0,05)$ yang artinya yang artinya ada perbedaan keterampilan perawat pelaksana di RSUD H. Hanafie Muara Bungo dengan RSUD Sultan Thaha Syaifudin Tebo. Hal ini berarti perlakuan yang diberikan peneliti pada kelompok intervensi telah berhasil meningkatkan keterampilannya.

Selanjutnya untuk kemampuan manajer kelompok intervensi dengan kelompok kontrol secara kumulatif didapati skor rata-rata post test kemampuan kelompok intervensi 145,35 kelompok kontrol 113,88 dengan $\mathrm{p}$ value $0,002(\mathrm{p}<0,05)$ yang artinya ada perbedaan kemampuan manajemen konflik perawat pelaksana di RSUD H. Hanafie Muara Bungo dengan RSUD Sultan Thaha Syaifudin Tebo. Hal ini berarti perlakuan yang 
Dewi Marlina et al, Efektivitas Pelaksanaan Terapi Empati terhadap Kemampuan Manejemen Konflik Perawat Pelaksana di RSUD H. Hanafie Muara Bungo Tahun 2019

diberikan peneliti pada kelompok intervensi telah berhasil meningkatkan kemampuannya.

\section{Pembahasan \\ Rata-rata Kemampuan Manajemen Konflik (Pengetahuan, Sikap dan Keterampilan) Perawat Pelaksana Sebelum dan Sesudah Pelaksanaan Terapi Empati pada Kemlompok Intervensi dan Kontrol \\ Pengetahuan}

Berdasarkan hasil penelitian yang telah dilakukan tentang kemampuan manajemen konflik (pengetahuan), peneliti mendapati hasil bahwa untuk kelompok intervensi, rata-rata pre test pengetahuan adalah 3,00 dengan skor terendah 2 dan tertinggi 4 . Selanjutnya untuk kelompok kontrol, rata-rata pre test pengetahuan adalah 2,94 dengan skor terendah 2 dan tertinggi 4. Hasil penelitian ini menunjukkan bahwa rata-rata pre test pengetahuan kedua kelompok masih perlu ditingkatkan.

Hasil penelitan ini sejalan dengan penelitian (Kahriman et al (2016) menyatakan bahwa nilai rata-rata pre test pengetahuan yaitu $6,3(60,3 \%)$ dari nilai total 10. Selanjutnya penelitian Gayanti (2018) juga menemukan bahwa rata-rata pre test pengetahuan masih relative rendah, yaitu $11(55 \%)$.

Menurut Bramley \& Matiti (2014) pengetahuan adalah informasi yang telah dikombinasikan dengan pemahaman dan potensi untuk menindaki yang lantas melekat di benak seseorang. Pengetahuan adalah hasil dari tahu dan hasil ini terjadi setelah seseorang melakukan penginderaan terhadap suatu objek tertentu. Pengeinderaan terjadi melalui panca indera manusia, yaitu penglihatan, pendengaran, penciuman, rasa dan raba (Notoatmodjo, 2014).

\section{Sikap}

Berdasarkan hasil penelitian yang telah dilakukan tentang kemampuan manajemen konflik (sikap), peneliti mendapati hasil bahwa untuk kelompok intervensi, ratarata pre test sikap adalah 40,06 (66,8\%) dengan skor terendah 36 dan tertinggi 44. Selanjutnya untuk kelompok kontrol, rata-rata pre test sikap adalah 39,94 $(66,6 \%)$ dengan skor terendah 34 dan tertinggi 49. Hasil penelitian ini menunjukkan bahwa rata-rata pre test sikap kedua kelompok juga masih perlu ditingkatkan.

Hasil penelitan ini sejalan dengan penelitian Berkhout \& John (2015) yang menemukan hasil bahwa nilai rata-rata pre test sikap yaitu $40(50,0 \%)$ dari nilai total 80. Selanjutnya penelitian Derksen (2013) juga menemukan bahwa rata-rata pre test sikap responden yaitu $(62,1 \%)$.

Hasil penelitan ini sejalan dengan penelitian Derksen (2013) juga menemukan bahwa rata-rata post test sikap responden yaitu $(87,9 \%)$.. selanjutnya penelitian Berkhout \& John (2015)Berkhout \& Jhon (2015) juga menemukan hasil bahwa nilai rata-rata post test sikap yaitu $70(87,5 \%)$ dari nilai total 80 .

\section{Keterampilan}

Berdasarkan hasil penelitian yang telah dilakukan tentang kemampuan manajemen konflik (keterampilan gaya penyelasaian konflik), peneliti mendapati hasil bahwa untuk kelompok intervensi, rata-rata pre test keterampilan adalah 70,76 (70,7\%) dengan skor terendah 65 dan tertinggi 77. Selanjutnya untuk kelompok kontrol, rata-rata pre test keterampilan adalah 70,65 (70,6\%) dengan skor terendah 34 dan tertinggi 49. Hasil penelitian ini menunjukkan bahwa rata-rata pre test keterampilan kedua kelompok juga masih perlu ditingkatkan.

Hasil penelitan ini sejalan dengan penelitian Mayfield (2018) yang menemukan hasil bahwa nilai rata-rata pre test keterampilan penyelesaian konflik yaitu $67,0(67,0 \%)$ dari nilai total 100 . Selanjutnya penelitian Altmann (2015) juga menemukan bahwa ratarata pre test keterampilan responden yaitu $(66,9 \%)$.

Selanjutnya pada penelitian ini juga dapat dilihat rata-rata keterampilan gaya penyelesaian konflik post test pada kelompok intervensi dan kontrol. Peneliti mendapati hasil bahwa untuk kelompok intervensi, ratarata post test keterampilan gaya penyelesaian konflik adalah 90,71 (90,7\%) dengan skor terendah 84 dan tertinggi 97. Selanjutnya untuk kelompok kontrol, ratarata post test keterampilan gaya penyelesaian konflik adalah 70,71 (70,7\%) dengan skor terendah 65 dan tertinggi 77.

Hasil penelitan ini sejalan dengan penelitian Altmann (2015) juga menemukan bahwa rata-rata post test keterampilan responden yaitu $(94,5 \%)$. Selanjutnya penelitian Mayfield (2018) juga menemukan hasil bahwa nilai rata-rata post test keterampilan penyelesaian konflik yaitu 95,5 (95,5\%) dari nilai total 100 .

Berdasarkan analisis kuesioner post test yang dilakukan oleh peneliti pada kelompok intervensi dan kelompok kontrol, peneliti menemukan adanya perbaikan skor kuesioner, yaitu pada kelompok intervensi, dari hanya $56,5 \%$ perawat yang mau mengakui kesalahan, menjadi 96,5\%. Sedangkan kelompok control tidak memiliki perubahan, yakni tetap $50,6 \%$.

\section{Pengaruh Perlakuan terhadap Kemampuan Manajemen Konflik (Pengetahuan, Sikap dan Keterampilan) Perawat Pelaksana pada Kelompok Intervensi dan Kontrol}

Berdasarkan hasil penelitian tentang pengaruh perlakuan terhadap kemampuan manajemen konflik (pengetahuan, sikap, keterampilan) perawat pelaksana pada kelompok intervensi dengan menggunakan uji statistik paired samplet-test (t-dependen) didapati $\mathrm{p}$ value pengetahuan 0,002, sikap 0,004 dan keterampilan 0,008 dan secara kumulatif didapatkan 0,007. Sedangkan pada kelompok kontrol didapati $\mathrm{p}$ value pengetahuan 0,163, sikap 0,726 dan keterampilan 0,579 dan secara kumulatif didapatkan 0,502. Hal ini berarti ada pengaruh 
yang signifikan dari pelaksanaan terapi empati terhadap kemampuan manajemen konflik perawat pelaksana di RSUD H. Hanafie Muara Bungo dan tidak ada pengaruh pada perawat pelaksana di RSUD Sultan Thaha Syaifudin Tebo.

Penelitian Klimecki (2019) membuktikan bahwa pelatihan empati dan empati yang dimiliki seseorang dapat mempengaruhi konflik yang terjadi baik secara individu maupun konflik antar kelompok. Selanjutnya Seehausen et al (2012) juga menemukan hasil bahwa dengan rasa empati yang tinggi dapat membuat seseorang mengatur emosinya dan menyelesaikan konflik dengan baik. lebih lanjut juga dismpulkan bahwa empati dapat merangsang pemrosesan emosi yang lebih intens membantu mengubah dan meningkatkan kemampuan manajemen konflikk (pengetahuan, sikap dan keterampilannya dalam menyelesaikan konflik).

Penelitian Sarmiento et al (2017) membuktikan bahwa empathy training sangat efektif untuk meningkatkan empati, perkembangan pelatihan eksperimental telah menunjukkan hasil yang positif. Berkhout \& John (2015) juga mendapati hasil bahwa training berdampak positif bagi peserta. Jadi dengan adanya terapi empati, peserta akan diberikan kesempatan untuk berpartisipasi dan diberikan materi mengenai pemahaman emosi agar dapat merasakan apa yang dirasakan oleh orang sehingga manajemen dalam menghadapi konflik semakin baik.

\section{Perbedaan Kemampuan Manajemen Konflik (Pengetahuan, Sikap dan Keterampilan) Perawat Pelaksana Sebelum dan Sesudah Diberikan Perlakuan Antara Kelompok Intervensi dengan Kelompok Kontrol} Berdasarkan hasil penelitian dapat diketahui perbedaan rata-rata kemampuan manajemen konflik (pengetahuan, sikap, keterampilan) antara kelompok intervensi dengan kelompok kontrol dengan uji statistik t-independen didapati skor rata-rata post test pengetahuan kelompok intervensi 4,53, kelompok kontrol 3,06 dengan $p$ value $0,003(\mathrm{p}<0,05)$ yang artinya ada perbedaan pengetahuan perawat pelaksana di RSUD H. Hanafie Muara Bungo dengan RSUD Sultan Thaha Syaifudin Tebo. Hal ini berarti perlakuan yang diberikan peneliti pada kelompok intervensi telah berhasil meningkatkan pengetahuannya. Kemudian skor rata-rata post test sikap kelompok intervensi 50.12 dan rata-rata post test sikap kelompok kontrol 40.12 dengan $\mathrm{p}$ value $0,010(\mathrm{p}<0,05)$ yang artinya yang artinya ada perbedaan sikap perawat pelaksana di RSUD H. Hanafie Muara Bungo dengan RSUD Sultan Thaha Syaifudin Tebo. Hal ini berarti perlakuan yang diberikan peneliti pada kelompok intervensi telah berhasil meningkatkan sikapnya. Kemudian skor rata-rata post test keterampilan kelompok intervensi $90 ., 71$ dan rata-rata post test keterampilan kelompok kontrol 70,71 dengan $\mathrm{p}$ value $0,005(\mathrm{p}<0,05)$ yang artinya yang artinya ada perbedaan keterampilan perawat pelaksana di RSUD $\mathrm{H}$. Hanafie
Muara Bungo dengan RSUD Sultan Thaha Syaifudin Tebo. Hal ini berarti perlakuan yang diberikan peneliti pada kelompok intervensi telah berhasil meningkatkan keterampilannya.

Kemampuan manajer kelompok intervensi dengan kelompok kontrol secara kumulatif didapati skor ratarata post test kemampuan kelompok intervensi 145,35 kelompok kontrol 113,88 dengan $\mathrm{p}$ value 0,002 ( $\mathrm{p}<$ $0,05)$ yang artinya ada perbedaan kemampuan manajemen konflik perawat pelaksana di RSUD $\mathrm{H}$. Hanafie Muara Bungo dengan RSUD Sultan Thaha Syaifudin Tebo. Hal ini berarti perlakuan yang diberikan peneliti pada kelompok intervensi telah berhasil meningkatkan kemampuannya.

Hasil penelitan ini sejalan dengan penelitian Osman (2018) di Sint yang mendapati hasil adanya perbedaan yang signifikan dari pengetahuan $(\mathrm{p}=0,009)$, sikap $(\mathrm{p}=0,018)$ dan keterampilan $(\mathrm{p}=0,021)$ responden dalam manajemen konflik antara kelompok intervensi dengan kelompok kontrol. Kelompok intervensi yang diberikan pelatihan memiliki kemampuan yang jauh lebih baik daripada kelompok yang tidak diberikan perlakuan.

Berdasarkan penelitian yang telah dilakukan peneliti di RSUD H. Hanafie Muara Bungo dengan RSUD Sultan Thaha Syaifudin Tebo. perbedaan rata-rata kemampuan manajemen konflik dapat dilihat pada analisis uraian kuesioner yang menunjukkan bahwa responden kelompok intervensi memiliki rata-rata pengetahuan, sikap dan keterampilan yang lebih tinggi dibandingkan dengan responden kelompok kontrol. Selain hal tersebut, dari analisis uraian kuesioner juga dapat diketahui adanya perbedaan peningkatan nilai ratarata antara kedua kelompok. Pada kelompok intervensi peningkatan nilai rata-rata pengetahuan $(1,52)$, sikap $(10,05)$, keterampilan $(19,94)$ dan secara kumulatif $(31,52)$. Sedangkan pada kelompok kontrol, peningkatan nilai rata-rata pengetahuan $(0,11)$, sikap $(0,17)$, keterampilan $(0,05)$ dan secara kumulatif $(0,3)$.

Menurut asumsi peneliti, perawat yang telah diberikan pelatihan ECT akan lebih memahami dan memiliki kemampuan manajemen konflik yang lebih baik dibandingkan dengan perawat yang tidak dilatih sama sekali. Oleh sebab itu peneliti berharap pada pihak RSUD H. Hanafie Muara Bungo untuk dapat mensosialisasikan kegiatan pelatihan ECT pada rumah sakit lainnya yang berada di wilayah Kabupaten Muara Bungo, agar perawat yang ada di rumah sakit tersebut dapat lebih terampil dalam mengelola konflik.

\section{DAFTAR PUSTAKA}

Altmann T. (2015). Evaluation of an Empathy Training Program to Prevent Emotional Maladjustment Symptoms in Social Professions. Psychology, 6(3), 1893-190.

Basogul C. (2016). Role of Emotional Intelligence in Conflict Management Strategies of Nurses. Asian 
Nursing Research, 3(2), 1-6.

Bassere, E., Gubert, F.SA., \& Martin, M. . (2017). Conflict management in nurse training. Journal of Nursing, 12(10), 2891-2896.

Berkhout, E.T.V., \& John, M. . (2015). The Efficacy Of Empathy Training: A Meta-Analysis Of Randomized Controlled Trials. Journal of Counseling Psychology, 63(1), 32-41.

Brunero. (2017). A Review of Empathy Education in Nursing. Nursing Inquiry, 17(1), 65-74.

Derksen F. (2013). Effectiveness of Empathy In General Practice: a Systematic Review. British Journal of General Practice, 5(2), 761-781.

Fatimatuzzahro A. (2017). Efektivitas Terapi Empati untuk Menurunkan Perilaku Bullying pada Anak Usia Sekolah Dasar. Jurnal Empati, 7(2), 362378.

Fernando M. (2017). Analisis Pengaruh Gaya Manajemen Konflik terhadap Kinerja Karyawan di Hotel Sheraton Surabaya. Jurnal Makara, 5(2), 453-465.

Fitri, N. \& Kamil, H. (2018). Hubungan Gaya Kepemimpinan Case Manager dengan Strategi Manajemen Konflik. JIM, 4(1), 92-97.

Gayanti T. (2018). Efektivitas Pelatihan Empathy Care untuk Meningkatkan Empati pada Mahasiswa Keperawatan. Jurnal Intervensi Psikologi, 10(1), 43-56.

Halpern, \& J. (2017). Empathy and Patient-Physician Conflicts. JGIM, 4(2), 696-700.

Hidaya N. (2017). Analisis Faktor-faktor yang Berhubungan dengan Bullying di Tempat Kerja Perawat Kota Bengkulu. Universitas Andalas. PAdang.

Jani B.D. (2017). The Role of Empathy in Therapy and the Physician- Patient Relationship. Jurnal Intervensi Psikologi, 3(19), 252-257.

Kahriman, I., Nural, N., Arslan, U., Tpbas, M., Can, G., Kasyim, S. (2016). The Effect of Empathy Training on the Empathic Skills of Nurses. Iran Red Crescent Med J, 18(6), 1-10.

Klimecki. (2019). The Role of Empathy and Compassion in Conflict Resolution. University of Geneva Journal, 3(1), 1-17.

Marettih A.K.E. (2016). Empathy Care Training for Increase Forgiveness On Last-Adolescense. Jurnal Intervensi Psikologi, 8(2), 285-3030.

Mayfield, \& L. (2018). Effect of Conflict Resolution Education on Nurse-Nurse Collaboration in a Community Hospital Setting. Nursing \& Health Care International Journal, 12(6), 1-15.

Notoatmodjo, S. (2012). Metodologi Penelitian Kesehatan. Jakarta: Rineka Cipta.

Osman F.E.S. (2018). Evaluate the Effect of EmpathyBased Training Program on Psychiatric Nurses' Communication Skills. . . IOSR Journal of Nursing and Health Science (IOSR-JNHS), 7(3),
32-41.

Sarmiento, P.B., Martina, F.G., Maria, B.B., Jose, M. R. S. (2017). Eficacy Of Empathy Training In Nursing Students: A Quasi Experimental Study. Journal Of Internet Nurse Education, 4(2), 442453.

Seehausen, M., Kazerr., Bajbouj., \& Prehn, K. (2012). Effects of Empathic Paraphrasing - Extrinsic Emotion Regulation in Social Conflict. Frontiers in Psychology, 4(2), 1-11. 